\title{
Factors Affecting The Investment Climate For An International Financial Center In Kuwait
}

\author{
Fouad Al-Salem, Ph.D., Gulf University For Science \& Technology, Kuwait \\ Mostafa Mohammed, Ph.D., Gulf University For Science \& Technology, Kuwait
}

\begin{abstract}
In recent years, an increasing worldwide interest in developing a competitive international financial center (IFC) raises the important issue of identifying the factors or elements of the investment climate of an IFC. Drawing on the theories and literature of financial intermediation, innovation, governance, social relationships, and information in IFCs, the authors develop five hypotheses and examine them using a survey of 200 MBA students at a private university in Kuwait. The findings obtained from conducting a hierarchical linear regression indicate that finance and innovation are positively and significantly related to the investment climate in an IFC. Implications for theory and practice, and areas of further research are made.
\end{abstract}

Keywords: International Financial Centers; Investment Climate for International Financial Centers in Kuwait

\section{INTRODUCTION}

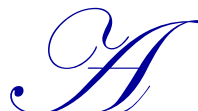

growing financial interdependence in the global economy is intensifying, and internationalization has accelerated (Grant and Venzin, 2009), especially in the financial industry, where there is a close interdependence of markets and institutions in the functioning and resilience of the financial system (BIS, 2008). The globalization of the financial services industry and markets, and the intensification of international financial integration create opportunities and present challenges to the participants in the financial intermediation process, in the development of global strategies for the provision of value. Given the importance of financial services for organizing the world economy, these activities create significant opportunities for value creation and capture (White, 2005). Increasingly, offshore financial centers are becoming key players in the "race" (Sikka, 2008), capturing a large share of global financial flows (Gonzalez and Schipke, 2011). A major type of offshore financial center is the international financial centers (IFCs) that are playing a dominant role in the international financial intermediation process (IMF, 2005). The theory of financial intermediation originated with Adam Smith's work $O n$ the Principles of Political Economy and Taxation (1817), however, it provided a 'passive' view on intermediation which is inadequate in explaining the reality of the finance industry (Lihui and Whinston, 2001). The traditional financial intermediation theory suggests the provision of basic value elements, such as liquidity and risk management (Allen and Douglas, 2004), and the allocation of resources (Woodford, 2010). However, no account is given to the value added elements as major outcomes of the process of financial intermediation. The challenge facing IFCs is developing a sound investment climate for the delivery of the elements or factors of value and value added to the agglomeration or cluster of financial institutions operating in it.

The definitions of an international financial center (IFC) (Gehrig, 1998., Goldberg and Levi, 2001., Zorome, 2007; IMF, 1994; Bhattacharya, 2011), share a common element of the provision of international financial transactions and services. In this study, an IFC represents an agglomeration of financial institutions that provide value competitively in the global financial marketplace. However, the existing definitions of investment climate in an IFC have a narrow and focus on institutional and regulatory elements. One definition of investment climate is: "The institutional, policy, regulatory environment in which firms operate: It is the collective set of incentives that establish the "rules of the game" to which economic actors must adhere". (Fan, Guillerme, and Jarvis, 2007). 
Another definition of investment climate is: "The policy, institutional, and behavioral environment, both present and expected, that influences the returns and risks associated with investment. The notion of investment climate focuses on questions of institutions, governance, policies, stability, and infrastructure that affect not just the level of capital investment but also the productivity of existing investments indeed, of all factors of production and the willingness to make productive investments for the longer term", (Stern, 2002). In this study, we define investment climate to capture more elements of value provided as: "the factors or elements of value provided by an IFC to the agglomeration of financial institutions operating in it".

The studies on investment climate, which is synonymous to the business environment (Morisett and Kelly, 2003, Hallward- Driemeier, Wallsten, and Xu, 2006) focus on its positive outcomes in terms of stimulating economic growth and development. (Hallberg, 2006, Kose et al. 2009, Weiss, 2008). However, most of the studies describe or prescribe the required institutional, governance, and infrastructure elements in an IFC (Negishi, 2007, DeFerranti, Jacinto, and Ody, 2009, Bhattacharya, 2011, Bindemann, 1999). In addition, they have a narrow geographic focus on Asia (Schenk, 2002, Jarvis, 2011, Laurenceson and Tang, 2005, Garcia-Herrera and Wooldridge, 2007) or Europe (Engelen, 2009, White, 2005), while African and Middle Eastern countries are understudied. The emergence of the Middle East as a global financial center is fueled by its oil revenues and equities (UNCTAD, 2008, IMF, 2009). The Arab World, especially the Gulf Cooperation Council (GCC) countries seek to establish an international presence by developing IFCs (Goetz, 2007). The limited nature of the studies on investment climate represent a gap in knowledge that needs to be addressed in an empirical study on an IFC located in a GCC country. The study comes in six parts. The first part is an introductory section indicating the growth of offshore finance with international financial centers playing an important role in the provision of value in the global financial marketplace. The second part is a literature review of factors of investment climate and five hypotheses, each relating to a relevant factor in the investment climate. The third part deals, with methodology, scales used, sampling, and the procedures conducted to implement the research design. The fourth part presents the results of the study, while in the fifth and sixth parts; we present conclusions, limitations, and future research needs.

\section{LITERATURE REVIEW AND HYPOTHESIS DEVELOPMENT}

In our literature review we will deal with the factors or elements of value affecting the investment climate in an international financial center. Based on an extensive review of the extant literature, we found that these factors might be classified as: finance, innovation, governance, social relationships, and information.

\section{Finance}

A modern economic system depends on a reliable and efficient flow of finance through the financial system comprising both financial markets and financial intermediaries. Financial resources are required to achieve the objectives set by organizations. The efficient allocation of risks and resources is the primary function of a financial system (Allen and Douglas, 2004). Financial institutions make the capital formation process more efficient and more attractive by providing services to the investors, creditors, and shareholders; managing risk is where real value is added in financial services. (Oldfield and Santomero, 1997, McDonough, 2002). Financial institutions bear and manage risk on behalf of their customers through the pooling of risks and the sale of their services as risk specialists (Saunders, 1997). A stream of research has found that the provision of liquidity and risk management are important basic factors of the investment climate in an IFC. A paper (Poon, 2003) examined the spatial organization and evolution of capital markets in forty- three world cities from 1980 to 1998, and concluded that the task of financial and capital centers is to mediate between surpluses and deficits of financial savings that are best matched in a central place. An empirical study (Gehrig, 1998) found that the future development of cities as financial centers depends on the relative importance and magnitude of "centrifugal and centripetal forces" in international financial markets, and the most important centripetal force derives from market liquidity. Risk adverse investors prefer to trade in liquid markets because the risk of price changes caused by liquidity shocks of individual traders is lower. In addition to liquidity provision in an IFC, risk management is important. IFCs add value to companies by minimizing it in offshore outsourcing (Weerakoddy and Irani, 2010). The discussion above suggests the following:

H1: The provision of finance (liquidity) is positively related to the investment climate in an IFC. 


\section{Innovation}

The positive impact of innovation on investment climate exists at both firm and country levels. Innovation may be the key for financial institutions to provide value-added products and services and differentiate themselves (Lihui and Winston, 2001). Key institutions besides factor endowments that can influence the location of production include national and regional systems of innovation, flexibility, and willingness to embrace innovation (Schneider and Susman, 2008). A paper (Walter, 1989) concluded that innovation is particularly important to players with a substantial presence in the offshore markets. These are typically markets where there are few barriers to competitive behavior, and where the relative absence of regulation allows each of the players far more degrees of freedom in terms of innovative behavior than is true in many onshore markets.

The discussion above suggests the following:

H2: Innovation is expected to be positively related to the investment climate in an IFC.

\section{Governance}

Adequate governance systems are essential to the development of a sound investment climate in an IFC. It includes several integrated elements: legal and regulatory systems, transparency, institutions, infrastructure, a stable political and macroeconomic environment, and capital account liberalization. A paper (Negishi, 2007) on East Asia and other emerging markets attempts to empirically answer what matters in the investment climate when a country wants to attract more long-term, stable foreign investment. A good investment climate includes sound macroeconomic policies, open regimes toward foreign investment, and non-discriminatory frameworks for business facilitation. An empirical study (Outreville, 2007) examined where financial firms are expanding their operations and documented some of the factors that may explain the most-favored locations of these financial groups. The results of the study indicated that location-specific advantages such as size, education, and cultural distance, do provide an explication for the establishment of foreign affiliates by the largest financial TNCs in specific locations. Second, that good governance has as strong impact on the choice of countries. A policy implication is that improving the functioning of markets and the institutional framework is critical for boosting long-run economic growth. Also, a theoretical study (Budd, 1995) prescribed the elements of a sound investment climate, in the form of systems of corporate governance, financial regulations, and general business environment as the means of maintaining a national interest as they become sites across which international transactions flow. The discussion presented above suggests the following:

H3: The presence of an adequate governance system is expected to be positively related to the investment climate of an IFC.

\section{Social Relationships}

Social relationships generate opportunities (Alderson and Beckfield, 2004., Polodny, Stuart, and Hannan, 1996). Relationships in the financial industry are long-term in nature and come to possess important attributes for the parties involved: reliability, trust, confidence, and security, which are critical to success (Maas and Graf, 2008), and economic growth rates (Beugelsdijk, 2006). Networked relations can also enhance certainty by enabling collaborative problem-solving, innovation, learning, and institutional change (Pistor, 2009; DePropris and Driffield, 2006). A study (Faulconbridge, et al., 2007) examined the factors affecting the competitiveness of a financial center, with a focus on Amsterdam as an IFC, and found evidence that even virtual financial markets have a "social underpinning" The process of knowledge creation and dispersion is facilitated by the relatively "tight spatial matrix" within which financial institutions locate themselves in leading IFCs, and the "dense social interactions" between traders within these matrices. The discussion above suggests the following:

H4: The development of social relationships is positively related to the investment climate in an IFC. 


\section{Information}

At the conceptual level, a study (Oldfield and Santomero, 1997) found that financial institutions provide more efficient discovery, evaluation, and dissemination of information about legitimate investment opportunities. It is considered a focal point in the field of entrepreneurship (Gaglio, 2004, Vaghely and Julien, 2010).

In a similar vein, agglomeration of financial institutions may result in a faster, more reliable information flow (Bindemann, 1999). A study (Faulconbridge, et al. 2007) on the competitiveness of Amsterdam as an IFC found that the clustering of financial institutions within IFCs leads to what has been described as "information spillovers". This is the process of knowledge creation and dispersion that is facilitated by the relatively tight spatial matrix within which financial institutions locate themselves in leading IFCs. Being embedded within such "spaces of knowledge" production and dispersion appears to be essential for conducting profitable trades. An empirical study (Gehrig, 1998) found that to the extent that the presence of other financial intermediaries stimulates communication among agents, more information can be exchanged among agents, and correspondingly exploited. Communication can help to generate new ideas but it also allows agents to benefit from information of others. The above discussion suggests the following:

H5: The production of information on entrepreneurial opportunities is positively related to the investment climate in an IFC.

\section{METHODOLOGY}

\section{Sample}

The surveyed participants were full and part-time MBA students at a large private university in Kuwait. There was a fairly close split between male $(55 \%)$ and female (45\%) participants. Furthermore, $48.3 \%$ of respondents had been in their position for five years and above, and $18.3 \%$ of respondents had been working in the present organization for over five years. In terms of positions, $65 \%$ of respondents were non-managerial; the remaining respondents were managerial (35\%). A total of 200 questionnaires were distributed. Each questionnaire included a covering letter explaining the aim of the study. For the purpose of maintaining confidentiality and anonymity, names of respondents were not solicited. In total, 90 students responded, generating an effective usable response rate of $45 \%$

\section{Measures}

Empirical studies on IFCs were the sources of the factors of the investment climate: finance, innovation, governance, social relationships and information. The factors were assessed on a five-point likert scale $(1=$ strongly disagree to $5=$ strongly agree). The first factor labeled "finance" included two items measuring the provision of liquidity and risk management systems (Poon, 2003, Gehrig, 1998, Weerakoddy and Irani, 2010). The second factor, labeled "innovation" included one item to measure the production of financial production and organization innovation (Faulconbridge, et al. 2007), and innovation conditions (Klein and HadjiMichael, 2003). The third factor labeled "social relationships" included three items to measure the development of social relationships for coordination, control, and problem- solving efforts, (Faulconbridge, et al. 2007, Pistor, 2009).The fourth factor labeled "governance" included nine items to measure the various aspects of governance. These elements include good governance elements (Deferrant, Jacinto, and Oday, 2009), infrastructure (Sekka and Veganzones-Varoudakis, 2007), financial institutions (Kose, Prasad, and Taylor, 2011), investment climate and regualtions (Negishi, 2007), educated manpower (Kinda, 2010), and the protection of investor rights (Iarossi, Mousley, and Radwan, 2009). The fifth factor labeled "information" included five items measuring the provision of information about investment opportunities, entrepreneurship, and innovation (Oldfield and Santomero, 1997., Gehrig, 1998), profitable trades (Faulconbridge et al. 2007), and future alliance decisions (Walter, 1989). 


\section{Procedures}

Since the scales had not previously been validated in an Arab non-Western context, the calculation of itemtotal correlations for the pooled data was first used as a basis for detecting poor items. Items with item-total correlation of 0.35 or less were eliminated from the analysis. Following recommendations by Anderson and Gerbing (1988), the retained items were subjected to an exploratory principal component analysis, separately for each scale, to further investigate the unidimensionality of the scales. We chose the oblique rotation since the survey dimensions are expected to be correlated. Advocates of the oblique rotation assert that in the real world important factors are likely to be correlated; thus searching for unrelated factors is unrealistic (Dixon, 1993). Finally, the retained items were combined into sum scales and reliabilities and means were calculated. The reliabilities, measured with Cronbach's alpha, ranged from 0.62 to 0.81 . Cronbach's alpha is considered for the most part to be a conservative estimate of a construct's reliability (Carmines \& Zeller, 1983).

\section{RESULTS}

\section{Product-moment correlations}

Though it does not prove causation, correlation can serve as predictor of causation (Sekaran, 2000). The product moment correlations between the variables are shown in Table 2. This table was constructed to get a feel for the associations among the six constructs constituting the model. Most of the correlation coefficients were significant and had the expected sign. Thus the constructs, in general, are highly related. (Table 1: Product Moment Correlations).

Table1. Product-moment correlations

\begin{tabular}{|c|c|c|c|c|c|c|c|}
\hline & & FIN & INV & GOV & INT & INF & INOV \\
\hline \multirow[t]{3}{*}{ FIN } & Pearson Correlation & 1 & $.670^{* * *}$ & $.741^{* *}$ & $.653^{* * *}$ & $.706^{* * *}$ & $.564^{* * *}$ \\
\hline & Sig. (2-tailed) & & .000 & .000 & .000 & .000 & .000 \\
\hline & $\mathrm{N}$ & 90 & 88 & 90 & 89 & 89 & 88 \\
\hline \multirow[t]{3}{*}{ INV } & Pearson Correlation & $.670^{* * *}$ & 1 & $.615^{* * *}$ & $.589^{* * *}$ & $.552^{* * *}$ & $.555^{* *}$ \\
\hline & Sig. (2-tailed) & .000 & & .000 & .000 & .000 & .000 \\
\hline & $\mathrm{N}$ & 88 & 88 & 88 & 87 & 87 & 86 \\
\hline \multirow[t]{3}{*}{ GOV } & Pearson Correlation & $.741^{* *}$ & $.615^{* *}$ & 1 & $.674^{* *}$ & $.706^{* * *}$ & $.531^{* *}$ \\
\hline & Sig. (2-tailed) & .000 & .000 & & .000 & .000 & .000 \\
\hline & $\mathrm{N}$ & 90 & 88 & 90 & 89 & 89 & 88 \\
\hline \multirow[t]{3}{*}{ INT } & Pearson Correlation & $.653^{* *}$ & $.589^{* *}$ & $.674^{* * *}$ & 1 & $.734^{* *}$ & $.722^{* *}$ \\
\hline & Sig. (2-tailed) & .000 & .000 & .000 & & .000 & .000 \\
\hline & $\mathrm{N}$ & 89 & 87 & 89 & 89 & 88 & 87 \\
\hline \multirow[t]{3}{*}{ INF } & Pearson Correlation & $.706^{* *}$ & $.552^{* *}$ & $.706^{* * *}$ & $.734^{* *}$ & 1 & $.639^{* *}$ \\
\hline & Sig. (2-tailed) & .000 & .000 & .000 & .000 & & .000 \\
\hline & $\mathrm{N}$ & 89 & 87 & 89 & 88 & 89 & 87 \\
\hline \multirow[t]{3}{*}{ INOV } & Pearson Correlation & $.564^{* *}$ & $.555^{* *}$ & $.531^{* * *}$ & $.722^{* *}$ & $.639^{* *}$ & 1 \\
\hline & Sig. (2-tailed) & .000 & .000 & .000 & .000 & .000 & \\
\hline & $\mathrm{N}$ & 88 & 86 & 88 & 87 & 87 & 88 \\
\hline \multicolumn{5}{|c|}{ **. Correlation is significant at the 0.01 level (2-tailed). } & & & \\
\hline
\end{tabular}


Table 2 Hierarchical regression results

\begin{tabular}{|c|c|c|c|c|c|c|c|c|c|c|}
\hline \multicolumn{11}{|c|}{ Model Summary ${ }^{f}$} \\
\hline \multirow[b]{2}{*}{ Mode } & \multirow[b]{2}{*}{$\mathrm{R}$} & \multirow[b]{2}{*}{ R Square } & \multirow[b]{2}{*}{$\begin{array}{c}\text { Adjusted R } \\
\text { Square }\end{array}$} & \multirow[b]{2}{*}{$\begin{array}{l}\text { Std. Error of } \\
\text { the Estimate }\end{array}$} & \multicolumn{5}{|c|}{ Change Statistics } & \multirow[b]{2}{*}{$\begin{array}{l}\text { Durbin- } \\
\text { Watson }\end{array}$} \\
\hline & & & & & $\begin{array}{l}\text { R Square } \\
\text { Change }\end{array}$ & F Change & df1 & $\mathrm{df} 2$ & Sig. F Change & \\
\hline 1 & $.081^{2}$ & .007 & -.018 & .77937 & .007 & .266 & 2 & 80 & .767 & \\
\hline 2 & $.581^{\mathrm{b}}$ & .338 & .312 & .64046 & .331 & 39.467 & 1 & 79 & .000 & \\
\hline 3 & $.707^{\mathrm{c}}$ & .500 & .475 & .55976 & .163 & 25.418 & 1 & 78 & .000 & \\
\hline 4 & $.713^{\mathrm{d}}$ & .509 & .477 & .55875 & .008 & 1.283 & 1 & 77 & .261 & \\
\hline 5 & $.714^{8}$ & .509 & .470 & .56204 & .001 & .100 & 1 & 76 & .752 & 1.893 \\
\hline \multicolumn{11}{|c|}{ a. Predictors: (Constant), GENDER, AGE } \\
\hline \multicolumn{11}{|c|}{ b. Predictors: (Constant), GENDER, AGE, INOV } \\
\hline \multicolumn{11}{|c|}{ c. Predictors: (Constant), GENDER, AGE, INOV, FIN } \\
\hline \multicolumn{11}{|c|}{ d. Predictors: (Constant), GENDER, AGE, INOV, FIN, GOV } \\
\hline \multicolumn{11}{|c|}{ e. Predictors: (Constant), GENDER, AGE, INOV, FIN, GOV, INF } \\
\hline \multicolumn{11}{|c|}{ f. Dependent Variable: INV } \\
\hline
\end{tabular}

Coefficients ${ }^{*}$

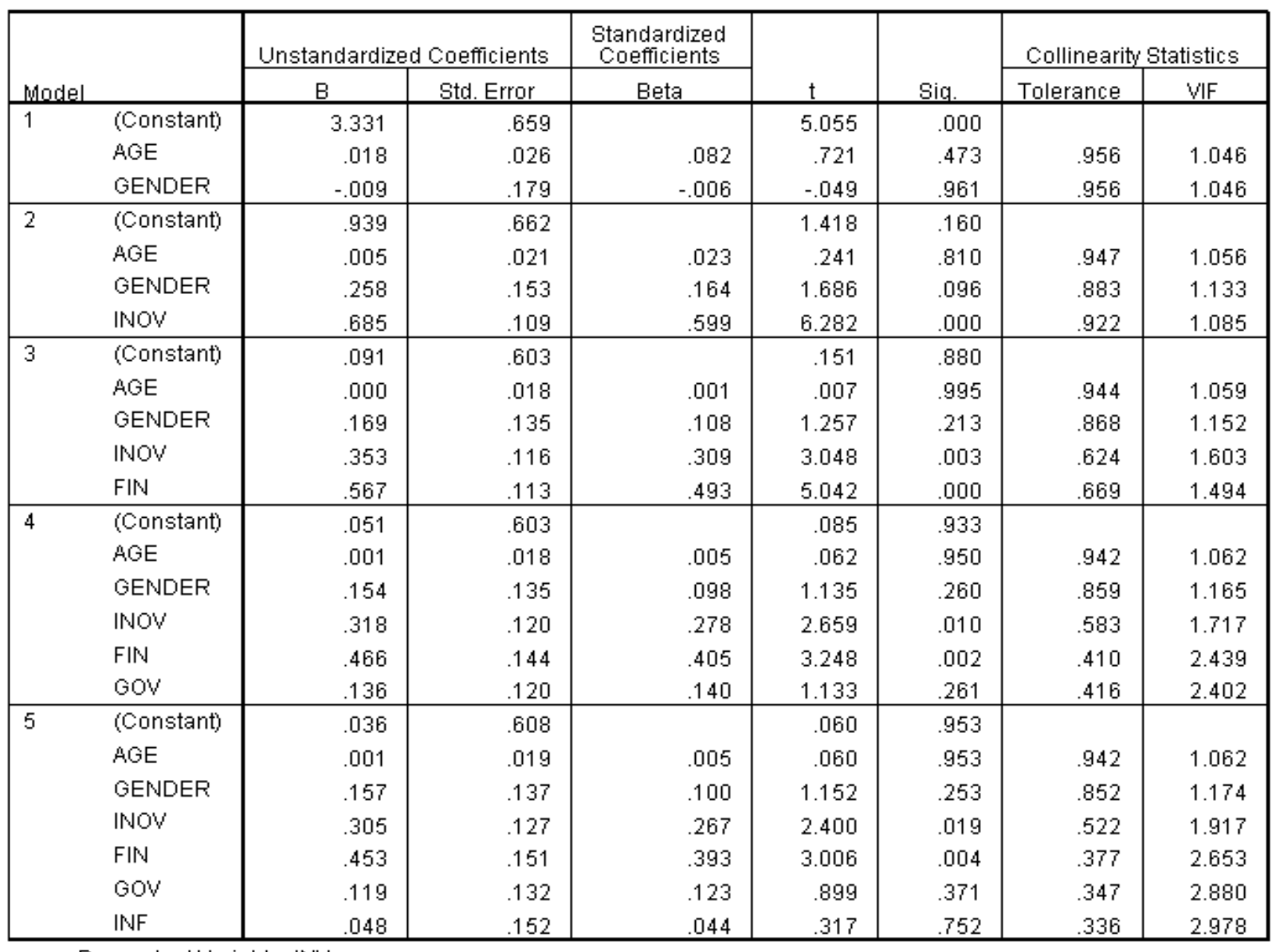

a. Dependent Variable: INV 


\section{Hierarchical regression analysis}

Hierarchical regression analysis was used to formally test the research hypotheses. This method is also known as incremental variance partitioning (Pedhazur, 1982). This approach allows us to focus on the variables forming the hypotheses, and at the same time sieve out the influence of the control variables that might have a moderating effect on affective commitment. Also this method allows the researcher to control the order of the variables entered into the regression model, allowing us to assess the incremental predictive ability of any variable of interest (McQuarrie, 1985).

Table -2- Hierarchical Regression Results shows the results of the hierarchical regression analysis used to test factors influencing international financial centers' investment climate. Following Geldern et al. (2008), gender and age were used as control variables in the first step of the regression. As shown in Table 1, the two variables were not significant at the 0.05 level. Both variables do not virtually explain any change in investment climate as indicated by the R-squared in model 1. This result corroborates previous research conducted in similar settings (e.g. Davey, Plewa \& Struwig, 2011). In fact, some authors argue that the explanations offered by demographic and personality factors are all distal in nature (e.g. Rauch \& Frese, 2000) since these explanations merely apply to broad classes of behaviour, which makes it difficult to formulate guidelines for intervention. In the second step, innovation variable was entered because previous research found a positive relationship between innovation and investment climate (Tate, Wendy, et al. 2009., Walter, 1989). The inclusion of this variable increased the explanatory power of the model to $33.8 \%$ (a change of around $39 \%$ in the R-squared). This change was found to be significant at the 0.001 level as shown in Table 2. In the third step, the finance variable was entered in the hierarchical regression analysis. This variable was entered based on previous research reporting a positive relationship between finance and investment climate (Gehrig, 1998). The inclusion of this variable increased the explanatory power of the model to 50\% (a change of around $16 \%$ in the R-squared). This change was found to be significant at the 0.001 level as shown in Table 2.

In the fourth step, the governance variable was entered and this variable explained almost nothing of the change in explanatory power of the model. In the fifth step, the information variable was entered and this variable also did not add anything to the explanatory power of the model. Taken together our results seem to confirm that the investment climate of international financial centers in Kuwait might be affected by innovation and finance. Diagnostic checks shown in Figure 1 showed that the hierarchical regression assumptions are not violated.

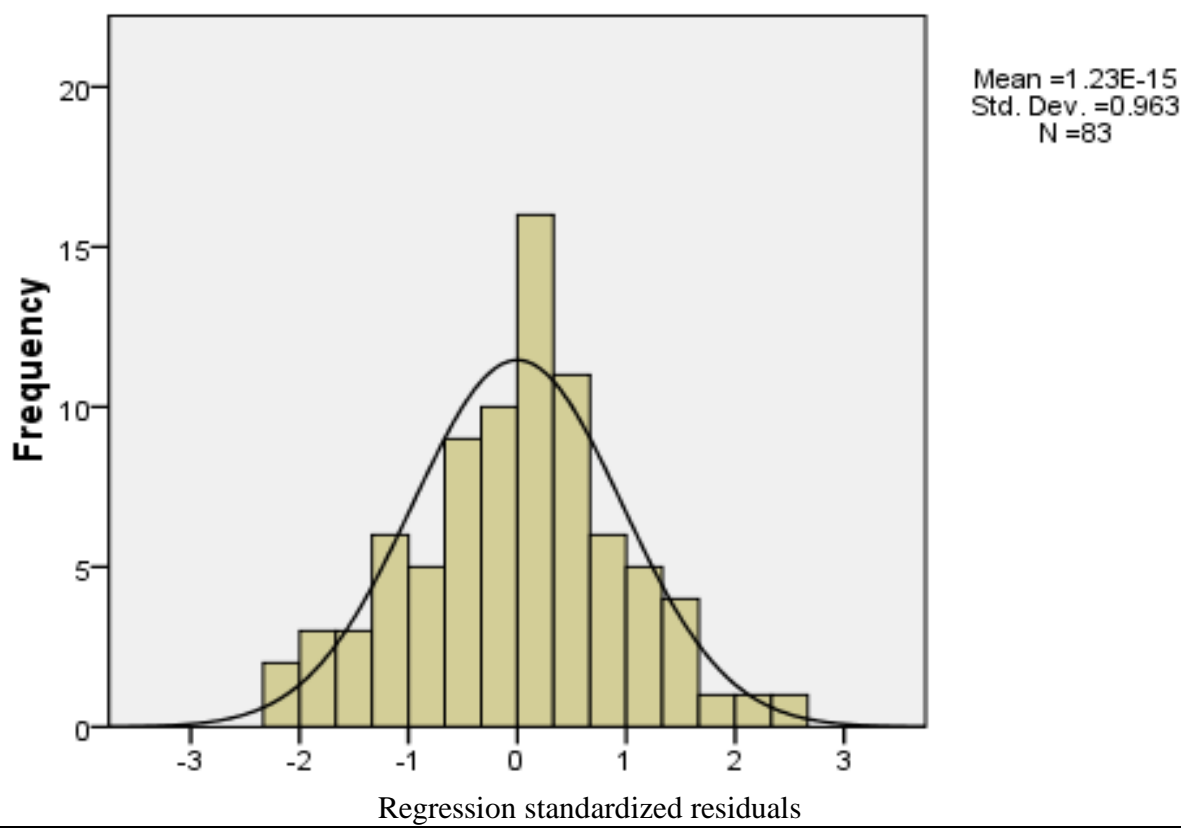

Figure1. Hierarchical regression standardized residuals 


\section{IMPLICATIONS, LIMITATIONS, AND FURTHER RESEARCH}

In this paper, we have attempted to suggest a more comprehensive group of factors, or value elements, of the investment climate in an IFC. As we mentioned in the introduction, most of the empirical studies on these factors have been narrow in scope. The focus of the studies is mostly on basic factors, such as finance, governance, infrastructure, and institutions, with little attention paid to other factors, of a value added nature, such as innovation, information, social relationships and entrepreneurship. This empirical study has attempted to fill this gap by testing five hypotheses relating to these factors: finance, innovation, information, social relationships, and entrepreneurship. On the basis of the results from the study, we have demonstrated the importance of finance, and innovation (value added) in the investment climate of an IFC. Also, with the increased interest in developing an IFC in many parts of the world, most of the studies on IFCs have a narrow geographic focus on Europe and the U.S.A. In order to cover more countries, the study was conducted in Kuwait, a member of the Gulf Cooperation Council (GCC).

The study has important implications for research and managerial practice; first, the realities and developments in the international financial market place show the inadequacy of the traditional view of financial intermediation, with its stress on basic factors or value elements. Hence, there is a need to broaden the scope of intermediation theory to consider more factors of a value added nature, such as innovation. In terms of practice, managers can enhance the effectiveness of an IFC by developing and implementing a comprehensive framework of factors, or value elements of the investment climate, in order to exploit its full potential. International marketers can develop better positioning strategies of IFCs as attractive sites for financial intermediation.

This study has limitations that could be extended in several ways. First, the data was collected from a sample of MBA students at a private university in Kuwait. The students do not necessarily have a full familiarity with or awareness of the investment climate of an IFC. Therefore, it is difficult to generalize the findings of the study to the working members of the financial and business community. Thus, additional research is needed to confirm the results of the study. Further research should focus on extending the generalizability of the findings by conducting a replication study on financial service employees in a diverse group of countries in the world. Second, the sample size of 90 observations is smaller than a normal sample size. A third limitation in the study is the language of the questionnaire, which was in English, administered to Arab students. Their understanding of the questions posed in the questionnaires could lead to a different understanding of what is being asked in the questions, which raises issues of the validity and reliability of the findings. Further research might focus on the existence of moderating effects of language differences in survey questionnaires.

\section{AUTHOR INFORMATION}

Fouad Al-Salem received his D.B.A degree from the George Washington University, Washington D.C. in 1978.He has also earned an M.B.A from the American University, Washington D.C. in 1975.He was employed at the University of Kuwait teaching a variety of management and marketing courses. He then joined the private sector as head of the foreign exchange and deposits section, representing the company on the boards of directors of banks in Paris and Athens. He was active in marketing the company in Europe. He then worked at the Central Bank of Kuwait in the banking supervision department. He managed a private business and then joined GUST in Kuwait as head of the Business Administration Department and an assistant professor till the present date. His current research interests include international marketing and international management, with a special interest and focus on the development of international financial centers in the GCC region. He published several articles in the Arabic language, the most recent in a major management periodical in Cairo. He also published in the International Journal of Islamic and Middle Eastern Finance and Management, and the International Journal of Management. He has also prepared more than 40 case studies on Kuwaiti and GCC companies to be used as teaching materials in class. E-mail: alsalem.f@gust.edu.kw (Corresponding author)

Mohamed M. Mostafa has received his PhD from the University of Manchester, UK. He has also earned an MS in Applied Statistics from the University of Northern Colorado, USA, an MSc in Functional Neuroimaging from Brunel University, UK, an MBA and a BSc at Port Said/Suez Canal University, Egypt. He was employed at universities in the USA, Portugal, Egypt, Cyprus, Jordan, United Arab Emirates, Bahrain and Kuwait. His current research interests include artificial Intelligence applications in business and marketing, neuromarketing/consumer 
neuroscience, art in advertising, social marketing and business efficiency. He has published over 50 research papers in several leading academic peer reviewed journals, including Psychology \& Marketing, Journal of Managerial Psychology, Journal of Promotion Management, Journal of Marketing Communications, International Journal of Consumer Studies, International Journal of Retail and Distribution Management, International Journal of Health Care Quality Assurance, Health Marketing Quarterly, Journal of Marketing for Higher Education, Journal of International Consumer Marketing, Qualitative Market Research, Global Business Review, Cross Cultural Management, Industrial Management \& Data Systems, International Journal of Productivity and Performance Management, International Journal of Business Performance Management, Expert Systems with Applications, Computational Statistics and Data Analysis, International Journal of Intelligent Computing \& Cybernetics, Neural Computing and Applications, Sustainable Development, International Journal of Sustainable Development \& World Ecology and the Journal of Economic Studies. He has also presented numerous papers at professional conferences worldwide. E-mail: Moustafa.M@gust.edu.kw

\section{BIBLIOGRAPHY}

1. Alderson, A. S. Beckfield, J. (2004), Power and Position in the World City System, American Journal of Sociology, 109 Issue. 4, 811-51.

2. Allen, F. and GaleDouglas, (2004), Financial Intermediaries and Markets, Econometrica 72, 4, p. 10231061.

3. Bank for International Settlements. (2008), 78 ${ }^{\text {th }}$ Annual Report 1 April 2007-31 March 2008.

4. Beugelsdijk, S. (2006), A Note on the Theory and Measurement of Trust in Explaining Differences in Economic Growth, Cambridge Journal of Economics. Vol. 30, Issue 3, p. 371-387.

5. Bhattacharya, A. K. (2011), The Feasibility of Establishing an International Financial Center in Shanghai, Journal of Asia- Pacific Business, 12:2, p. 123-140.

6. Bindemann, K. (1999), Future of European Financial Centers. Florence, KY, U.S.A: Routledge.

7. $\quad$ BIS $78^{\text {th }}$ Annual Report 30 June 2008.

8. Budd, L. (1995), Globalization, Territory and Strategic Alliances in Different Financial Centers. Urban Studies, Vol, 32 Issue 2, p. 345-361.

9. De Ferranti, D., Jacinto., and Ody, A. How to Improve Governance: A New Framework for Analysis and Action. Washington, DC, USA: Brookings Institution Press, 2009. P.23.

10. De Propris, L. Driffield, Nigel, (2006), The Importance of Clusters for Spillovers from Foreign Direct Investment and Technology Sourcing, Cambridge Journal of Economics. p. 277-291.

11. Engelen, E. Grote, Michael H. (2009), Stock Exchange Virtualization and the Decline of Second- Tier Financial Centers- The Cases of Amsterdam and Frankfurt, Journal of Economic Geography; Vol. 9 Issue 5, p. 679-696.

12. Fan, Q., Reis, J. G., and Jarvis, M. Investment Climate in Brazil, India, and South Africa. Herndon, VA, USA: Worls Bank Publications, 2007. P VI.

13. Faulconbridge, J., Engelen, E., Hoyler, M., and Beaverstock, J. (2007), Analyzing the Changing Landscape of European Financial Centers: The Role of Financial Products and the Case of Amsterdam, Growth and Change, Vol. 38, No, 2: 279-303.

14. Gaa, C., Lumpkin, S., Ogrodnik, R., and Thurlow, P. (2001), The Future Prospects for National Financial Markets and Trading Centers, Bank of Canada Working Paper 2001- 2010.

15. Gaglio, C. M. (2004), The Role of Mental Simulations and Counterfactual Thinking in the Opportunity Identification Process, Entrepreneurship Theory and Practice.

16. Garcia-Herrero, A., and Wooldridge, P. (2007), Global and Regional Financial Integration, BIS Quarterly Review.

17. Gehrig, T. (1998), Cities and the Geography of Financial Centers, Discussion Paper Series No. 1894, Centre for Economic Policy Research. www.cepr.org.june1998.

18. Goetz, V.P. (2007), International Banking Centres, A Network Perspective BIS Quarterly Review. Part 3.

19. Goldberg, M., and Levi, M. D. (2001), On the Development of International Financial Centres, Faculty of Commerce and Business Administration. University of British Columbia, Vancouver, Canada.

20. Gonzalez, M., and Schipke, A. (2011), Bankers on the Beach, Finance and Development, Vol. 48 No. 2.

21. Grant, R. M., Venzin, M. (2009), Strategic and Organizational Challenges of Internationalization in Financial Services, Long Range Planning. Volume 42, Issues 5-6 p. 581-587. 
22. Hallward- Driemeier, M., Wallsten, S., Xu, L. C. (2006), Ownership Investment Climate and Firm Performance Evidence from Chinese Firms, Economics of Transition, Vol. 14 (4), p. 629-647.

23. Hallberg, K. (2006), Improving Investment Climates: An Evaluation of World Bank Group Assistance. Herndon, VA, USA: World Bank Publications, p. (2).

24. International Monetary Fund, (1994), The Role Offshore Centers in International Financial Intermediation, International Monetary Fund WP/94/107-EA www.imf.org

25. International Monetary Fund, (2009), Regional Economic Outlook Middle East and Central Asia. World Economic and Financial Surveys.

26. International Monetary Fund, (2009), Global Financial Stability Report.

27. International Monetary Fund, (2005), Financial Sector Assessment A Handbook. www.imf.org

28. Jarvis, D.S.L. (2011), Race for the Money: International Financial Centers in Asia, Journal of International Relations and Development Vol. 14 Issue 1, p. 60-95.

29. Kikeri, S. K., and Thomas, P. V. (2006), Reforming the Investment Climate: Lessons for Practitioners. World Bank Publications, Herndon, UA, U.S.A.

30. Kinda, T. (2010), Investment Climate and FDI in Developing Countries: Firm-Level Evidence, World Development, Vol. 38, No. 4, pp. 498-513.

31. Klein, M., Hadjimichael, B. (2003), Private Sector in Development: Entrepreneurship, Regulation, and Competitive Disciplines.

32. Kose, A.M., Prasad, E.S., and Taylor, A. D. (2011), Thresholds in the process of international financial integration, Journal of International Money and Finance, Elsevier, Vol. 30(1), pages 147-179.

33. Kumar, A., Francisco, M. (2005), Enterprise Size, Financing Patterns, and Credit Constraints in Brazil: Analysis of Data From the Investment Climate Survey. Washington D.C., U.S.A: World Bank Publications.

34. Laurenceson, J., and Tang K. K. (2005), Shanghai's Development as an International Financial Center, Review of Pacific Basin Financial Markets Policies. Vol. 8, No. 1, p. 147-166.

35. Lihui, L., Xianjun, G., and Whinston, A. (2001), A New Perspective to Finance and Competition and Challenges for Financial Institutions in the Internet Era, BIS Papers No. 7. Available online at www.bis.org/publ

36. Maas, P., and Graf, A. (2008), Customer Value Analysis in Financial Services, Journal of Financial Services Marketing. Vol. 13, 2 (107-120).

37. McDonough, W. J. (2002), Issues in Corporate Governance, Current Issues in Economics and Finance, Vol. 8 No. 8, p. 1-6.

38. Morisett, J., and Andrews-Johnson, K. (2003) The Effectiveness of Promotion Agencies at Attracting Foreign Direct Investment. Foreign Investment Advisory Service. Occasional Paper 16. 2003.

39. Negishi, S. (2007), External Finance and Investment Climate in East Asia and Other Emerging Markets, Asian Economic Papers, 6:1, p. 74-100.

40. Oldfield, G. S., and Santomero, A. M. (1997), Risk Management in Financial Institutions, Sloan Management Review vol. 39 Issue 1, p. 33-46.

41. Outreville, F. J. (2007), Foreign Affiliates of the World Largest Financial Groups: Locations and Governance, Research in International Business and Finance, 21, p. 19-31.

42. Pagano, M., and Volpin, P. (2006), Shareholder Protection, Stock Market Development, and Politics, Journal of the European Economic Association. 4 (2-3): 315-341.

43. Pistor, K. (2009), Global Network Finance: Institutional Innovation in the Global Financial Marketplace, Journal of Comparative Economics. Vol. 37, Issue 4, p. 552-567.

44. Polodny, J. M., Stuart, T. E., and Hannan, M. T. (1996), Networks, Knowledge, and the Niches: Competition in the Worldwide. Semiconductor Industry, 1984-1991, American Journal of Sociology. Vol. 102, No. 3, p.659-689.

45. Poon, J. P.H. (2003), Hierarchical Tendencies of Capital Markets Among International Financial Centers, Growth and Change, Vol. 34, No. 2, p. 135-156.

46. Ricardo, D. (1817), Principles of Political Economy and Taxation. London, GBR: Elec Book.

47. Saunders, A. (1997) Financial Institutions Management, A Modern Perspective. Second Edition. Irwin, Burr Ridge, Illinois.

48. Sekkat, K., Veganzones-Varoudakis, Marie. A. (2007), Openness, Investment Climate, and FDI in Developing Countries, Review of Development Economics, 11 (4), p. 607-620. 
49. Schenk, C. R. (2002), Banks and the Emergence of Hong Kong as an International Financial Center, Journal of International Financial Markets, Institutions, and Money; Vol. 12 Issue 4/5, p. 321-340.

50. Scherer, B., and Xu, X. (2007), The Impact of Constraints on Value-Added: A Non: Cynical Approach, The Journal of Portfolio Management.

51. Schneider, G., and Susman, P. (2008) Trade People and Places: A Social Economic Geographic Approach to Comparative Institutional Advantage. Review of Social Economy, Vol. 66 Issue 4, p. 469-499.

52. Sikka, P. (2008), Globalization and its Discontents, Accounting, Auditing, and Accountability Journal. Vol. 21, Issue 3, p. 398-426.

53. Slater, S. F. and Narver, J. C. (2000), Intelligence Generation and Superior Customer Value, Journal of the Academy of Marketing Science. Vol. 28, No. 1. P. 120-127.

54. Smith, H. A., and Mckeen, J. D. (2005), Developments Knowledge Management: Auditing Value for our Customers, Communications of the Association for Information Systems. Volume 16, 744-755.

55. Stern, N. Strategy for Development. Washington, DC, USA: World Bank Publications, 2002. P iv.

56. Tate, W. L., Ellram, L.M., and Brown, S, W. (2009), Offshore Outsourcing of Services, Journal of Service Research. Vol. 12, Iss. 1, p. 56-72.

57. United Nations Conference on Trade and Development. (2008), "World Investment Report 2008," Transnational Corporations and the Infrastructure Challenge.

58. Vaghely, I. P., and Julien, P. A. (2010), Are Opportunities Recognized or Constructed? An information Perspective on Entrepreneurial Opportunity Identification, Journal of Business Venturing. Vol. 25, Issue 1, p. 73-86.

59. Walter, I. (1989), Competitive Positioning in International Financial Services, Journal of International Financial Management and Accounting, Vol. 1, Issue 1, p. 15-40.

60. Walter, I. (2009), Economic Drivers of Structural Change in the Global Financial Services Industry, Long Range Planning. Volume 42, Issues 5-6, p. 588-613.

61. Walter, I., and Elif. S. (2007), The Asset Management Industry in Asia: Dynamics of Growth, Structure, and Performance Financial Markets, Institutions and Instruments. Volume 16, Issue 1, p. 1-77.

62. Warnock, F., and Cleaver, C. (2003), Financial Centers and the Geography of Capital Flows, International Finance. 6:1, pp. 27-59.

63. Webster, A., and Hardwick, P. (2005), International Trade in Financial Services, The Services Industries Journal. Vol. 25, No. 6, p. 721-746.

64. Weiss, J. (2008), Investment Climate in China: Province Estimates, Journal of the Asia Pacific Economy, Vol. 13, No. 3, p. 260-273.

65. Weerakoddy, V., and Irani, Z. (2010), A Value and Risk Analysis of Offshore Outsourcing Business Models: An Exploratory Study, International Journal of Production Research 48 (2): 613-634.

66. White, M. C. (2005), Assessing the Role of the International Financial Services Center in Irish Regional Development, European Planning Studies. Vol. 13, No. 3, p. 387-405.

67. Williams, A. (2009), On The Release of Information by Governments: Causes and Consequences, Journal of Development Economics. Vol. 89 Issue 1, p. 124-138.

68. Woodford, M. (2010), Financial Intermediation and Macroeconomic Analysis, Journal of Economic Perspectives, Vol. 24, Issue 4, p. 21-44.

69. Yoshikuni, S. (2008), Asia as a Financial Center-Opportunities and Obstacles, Journal of Asset Management. Vol. 9, 2, 80-89.

70. Zorome, A. (2007), Concept of Offshore Financial Centers: In Search of an Operational Definition, IMF Working Paper, Monetary and Capital Markets Department. 


\section{APPENDIX: RESEARCH INSTRUMENT}

1. An international financial center should provide a reliable flow of financing and liquidity

2. An international financial center should provide effective and efficient risk management systems

3. An international financial center should be located in country that enjoys an attractive Investment climate.

4. An international financial center should be located in country that enjoys macroeconomic and political stability.

5. An international financial center should have a well-functioning financial system, institutions, and capital markets.

6. An international financial center should have appropriately-designed governance structures (stable, transparent and predictable regulatory conditions).

7. An international financial center should provide adequate financial market infrastructures (tax regimes, procedures, and laws).

8. An international financial center should provide protection of investors' rights.

9. An international financial center should have talented and skilled labor and educated manpower.

10. An international financial center should provide knowledge and information about market and investment opportunities.

11. An international financial center should provide Information on competitors.

12. An international financial center should provide adequate information on future alliance decisions.

13. An international financial center should have a well-established IT-infrastructure.

14. An international financial center should be located in country that enjoys financial liberalization.

15. An international financial center should promote the production and innovation of financial and intellectual capital.

16. An international financial center should provide a well-established opportunity identification system.

17. An international financial center should provide opportunities for engaging in entrepreneurial activities.

18. An international financial center should follow the evolution of social networks (Facebook, Twitter).

19. An international financial center should provide an inter-firm coordination and collaboration system to enable collaborative problem-solving efforts.

20. An international financial center should develop trust and interpersonal relations in a global workplace for coordination and control purposes. 